\title{
ЕПИГРАФСКИ СПОМЕНИК ИЗ ЖУПАЊЕВЦА У ЗБИРЦИ НАРОДНОГ МУЗЕЈА У КРАГУЈЕВЦУ
}

\author{
Александар Ристић \\ Народна библиотека „Др Милован Спасић” Рековац \\ Филозофски факултет, Универзитет у Београду
}

\begin{tabular}{r|c} 
e-mail: arh.aleksandar.ristic@gmail.com & Оригинални научни рад \\
Примљено: 28. 4. 2020. & УДК: 069.51:904"15/16"(497.11) \\
Прихваћено: 4. 9. 2020. & $904: 726.825 " 653 "(497.11)$
\end{tabular}

\begin{abstract}
Апстракт: У археолошкој збиричи Народног музеја у Крагујевиу налази се камени споменик који потиче из села Жупањеваи, насеља које припада суседној општини Рековач. На њему се налази текст ктиторско-меморијалног карактера, из кога се сазнаје да је споменик подигао локални кнез у сећање на своју кнегињу Анђелију, као и то да га је направио извесни занатлија Вранеш. До сада није било израженијег научног интересовања за овај споменик, већ је о юему узгредно писано од прве половине 19. века. На юега се први осврнуо учитељ из Свилајнца Јован Живановић у свом раду о „Граду Жупағевиу”, објављеном у листу Подунавка 1843. године, где је предочио своје виЂење читањ а текста на споменику. Други пут је споменут у 19. веку у делу Феликса Канииа, код кога није изазвао веће интересоваье, јер се није радило о римском споменику како је очекивао. Од тог периода, овај споменик је свега неколико пута узгредно поменут, без детаљније анализе. У овом раду су приложени опис, стилска анализа споменика и извриен је покушај нешто приближнијег датовања.
\end{abstract}

Кључне речи: камени споменик, ћирилички натпис, Народни музеј Крагујеваи, Жупањевац, Левач, Белега, кнез, османски период

Део атара села Жупањевац под именом Белега, на коме се налазио епиграфски споменик који представља тему овог рада, простире се на југоисточној страни атара, са леве и десне стране данашњег пута који у насеље води из правца истока. ${ }^{1}$ У питању је заселак на ком се налазе данашња сеоска домаћинства и обрадиве површине. Реч „белег” у српском језику, између осталог, означава „надгробни споменик”, као и камен „међаш“ (Лома 2008, 83). Међе су у средњовековним сеоским атарима могле бити, осим природних, и вештачке, па су према томе обележаване и камењем укопаним у земљу на којима су се могле налазити одређене ознаке. У функцији значења „међе”, ову реч срећемо у повељи краља Стефана Уроша III из 1325. године, на осно-

\footnotetext{
${ }^{1}$ Топографска карта 531-1-3 Kruševac 1-3 (Rekovac) 1:25000.

Гласник Српског археолошког друштва

Journal of Serbian Archaeological Society 
ву које се прилажу одређена села манастиру Хиландару - „мєгґ тємьзн сєломь

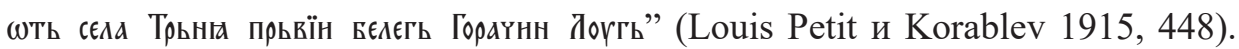
Такође, налазимо и податак по ком је међа селу Србици код Призрена 1348. године ишла „оү вњ九Һгє коүдь поставнсмо мраморєе” (Шафарикь 1862, 274-275), а у међе села Пирама са Крушијем су била укопана четири „мрамора” и два „камена” (Благојевић 1999, 38). Доста касније, у једној дечанској повељи из 1565. ова се реч такође користи да би означила одређену међу (границу) -

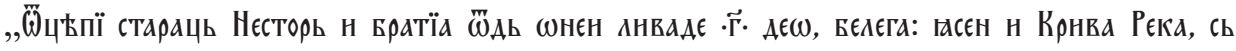
єдне стране Хасанова анвада, с авБ стране Жнвков стоп" (Стојановић 1923, 64). Као ознаку за надгробни споменик, ову реч чешће срећемо у натписима на стећцима (Стојановић 1902, 74; Bešlagić 1982, 32; Зечевић 2005, 77; Лома 2008, $86)$, док се у појединим документима назив белег јавља и као топоним - „ог

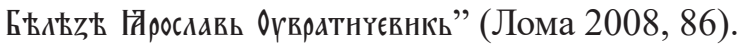

За Белег у Жупањевцу и споменик на том месту први пут сазнајемо из једног новинског чланка који је објавио свилајначки учитељ Јован Живановић у листу Подунавка 1843 . године. Након описа утврђења Град у Жупањевцу и препричавања сеоских легенди о њему, Јован Живановић говори о ,једном усред поља дупке побијеном камену”, 500-600 корака у правцу истока ${ }^{2}$, на коме је „грдним словима” исписан текст - „Постави ови каменъ Кнезъ Иванъ-Бегъ Кнегинъи Анђеліи, а направи га Вранешъ майстор”. У фусноти стоји објашњење да је „саобштитель” преписао текст у истој форми као што је на камену, па га је аутор тако и прочитао (Живановић 1843, 193). У наставку се говори о легенди, према којој је кнегиња Милица са овог места топовима гађала Николу Жупана, који је боравио у утврђењу Град. Након што је усмртила поменутог жупана, кнегиња Милица се вратила и поставила камен на Белеги као знак свог доласка у Жупањевац. У фусноти након ове приче Јован Живановић закључује да прочитани натпис „сасвим друго казује, како се види" (Живановић 1843, 194). ${ }^{3}$ Путописца и истраживача Ф. Каница су мештани упутили до усамљеног „биљега” који „нико не уме да прочита". Пошто се није радило о римском споменику како је очекивао, Феликс Каниц није оставио подробнији опис овог споменика и записао је само да се на њему налазе „искривљена црквенословенска слова” (Каниц 2007, 625). Тодор Бушетић 1903. године помиње „камен побијен у земљу” у дну села Жупањевац, који је према његовој процени био висок 1,5 м од нивоа земље. Као и Јован Живановић, он подсећа на предање о рушењу града Николе Бољара топовима са тог места (Бушетић 1903, 496).

\footnotetext{
${ }^{2}$ Ради се о удаљености већој од једног километра.

${ }^{3}$ Ово предање о сукобу кнегиње Милице и Николе Жупана може се чути и код данашњих мештана села Жупањевца.
} 


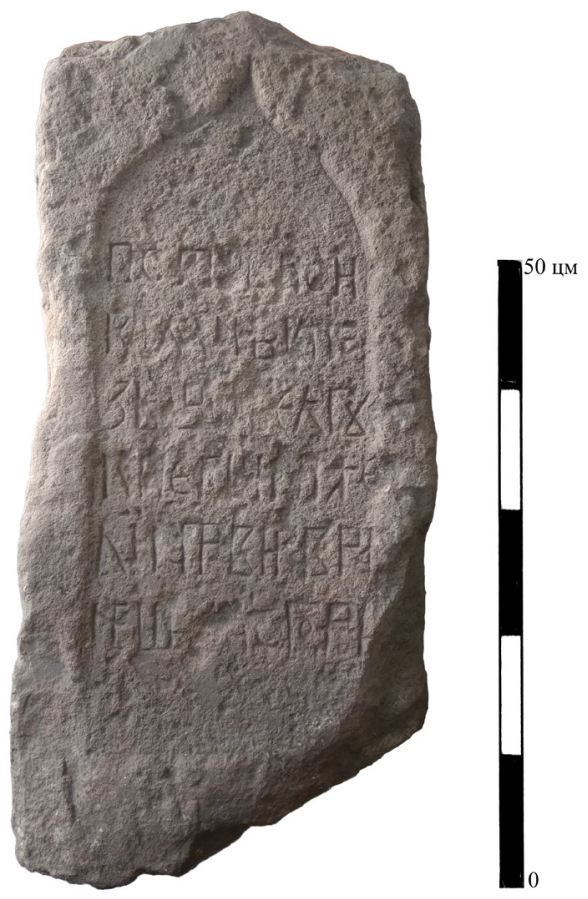

Сл. 1. Епиграфски споменик из Жупањевца

Fig. 1. Epigraphic monument from Županjevac

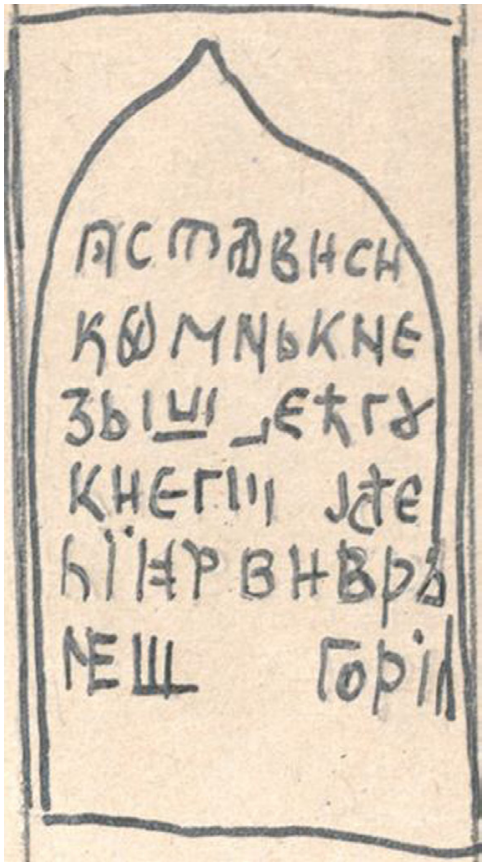

Сл. 2. Скица споменика из инвентарне књиге Народног музеја у Крагујевцу

Fig. 2. Drawing of a monument from the inventory book of the National Museum in Kragujevac

Камени споменик који потиче са „локалитета” Белега у селу Жупањевац заведен је у инвентарној књизи Народног музеја у Крагујевцу под редним бројем 3147 (сл. 1). У напомени стоји да је предмет био узидан у зид штале Стојанке Савић, а да је пре тога стајао укопан поред пута недалеко одатле. Посредством Богољуба Мркића 1955. године постао је музејско власништво. Наредна рубрика инвентарне књиге садржи број 100.000, што по свему судећи представља износ који је музеј издвојио за откуп споменика. У продужетку колоне је приложена и скица споменика са делимично прочитаним натписом, као и опис врсте материјала од кога је сачињен (сл. 2). ${ }^{4}$

Поред података из инвентарне књиге, из сведочења мештана се такође сазнаје да је са првобитне локације камен однесен и узидан у шталу,

\footnotetext{
${ }^{4}$ Инвентарна књига Народног музеја у Крагујевцу, бр. 3147. Овом приликом захваљујемо археологу кустосу Народног музеја у Крагујевцу Игору Ђуровићу на уступљеном музејском предмету, на подацима из инвентарне књиге, као и на могућности да се изврши RTI анализа споменика и изради његов 3D модел.
} 


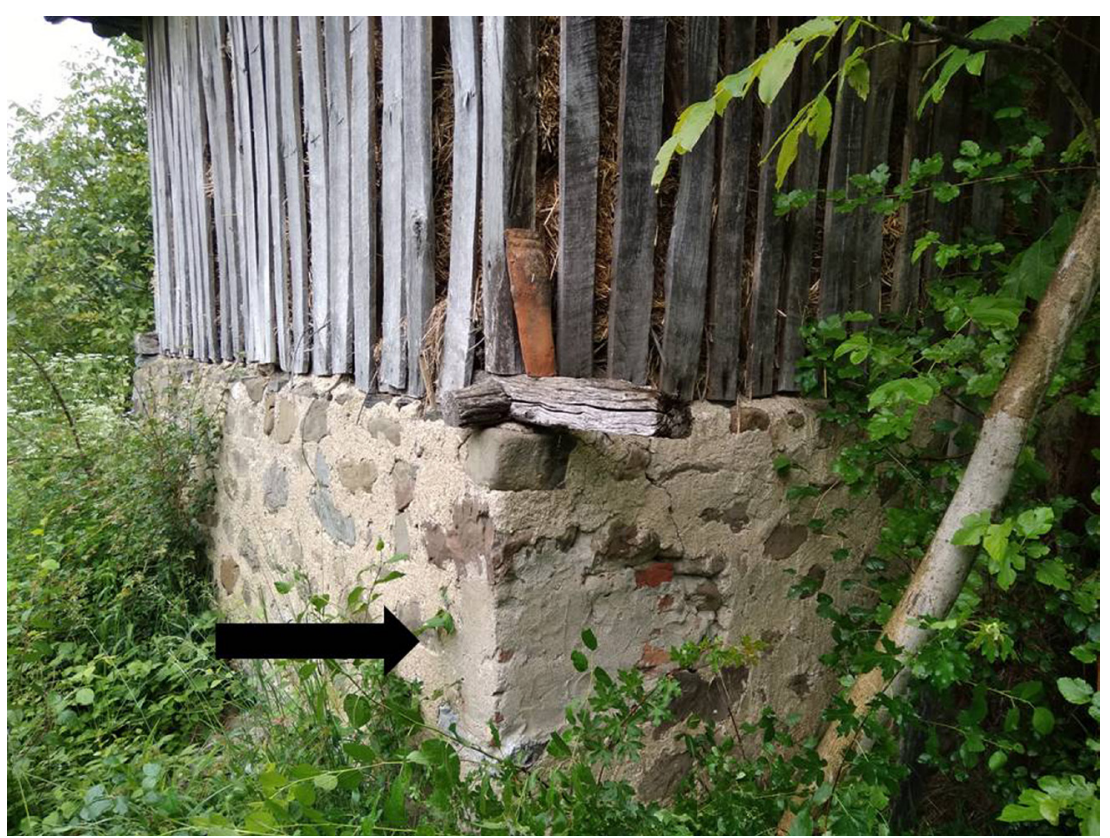

Сл. 3. Зграда у чијем зиду је споменик био узидан (са назначеном позицијом) (фото А. Ристић)

Fig. 3. Building with the stone built in (with its position marked) (photo by A. Ristić)

како би после одређеног времена био извађен и пренесен у крагујевачки музеј (Марковић 2004, 158, 163). ${ }^{5}$ На Белеги још увек постоји поменути објекат и налази се са десне стране старог пута који води од Жупањевца према Богалинцу. Ради се мањој правоугаоној згради са озиданим приземним делом, где је и данас видљиво лежиште на његовом југозападном углу, у који је споменик био хоризонтално узидан. Позиција извученог споменика се добро уочава услед накнадног малтерисања отвора насталог услед његовог извлачења (сл. 3). Пошто је споменик веома тежак, по свему судећи се налазио негде у непосредној близини поред поменутог пута који пролази поред објекта, као што је и записано у инвентарној књизи Народног музеја у Крагујевцу. ${ }^{6}$

\footnotetext{
${ }^{5}$ Сведочење о померању и искоришћавању споменика у грађевинске сврхе дао је Хранислав Ракић из Жупањевца, рођен 1925. године. С обзиром на то да у излагању наводи да је споменик са натписом стајао на првобитној локацији док је био дете, претпостављамо да је извађен и узидан у објекат највероватније током тридесетих година 20. века. За предања о споменику белеги и другим споменицима и налазиштима у селу Жупањевцу види : Марковић 2004, 157-166.

${ }^{6}$ Данашњи најстарији мештанин села Жупањевац не зна где би могла бити тачна првобитна локација овог споменика.
} 


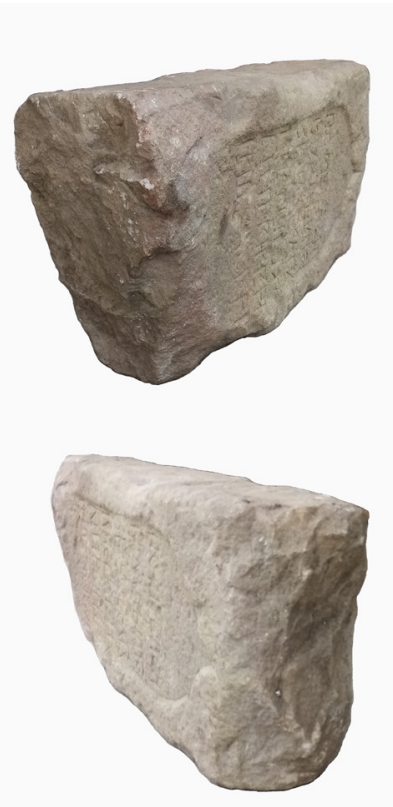

Сл. 4. Доња и горња страна споменика са видљивим оштећењима

Fig. 4. The lower and the upper part of the monument with visible damaged parts

Дужина овог споменика правоугаоног пресека, израђеног од кречњака, износи 68 цм, ширина 30-31 цм, док дебљина достиже између 15-17 цм са десне и до 18 цм са леве стране. Споменик је оштећен подједнако на горњој и доњој страни, што се највише уочава на доњем делу, где је укосо „засечен” (сл. 4). На једној од ширих страна исклесан је „оквир” за потребе формирања натписа. Ивице тог поља паралелно прате дуже стране споменика, да би се у горњем делу постепено савијале формирајући тако полукружни облик. При самом врху, линије се извијају у супротном смеру, спајају се и чине зашиљени врх. На обе „кривине” које се спајају у зашиљени врх налази се по један декоративни испуст ка спољашњости у виду „шиљка”, од којих је онај са леве стране нешто уочљивији (сл. 5). ${ }^{7}$ Чини се да се један такав испуст налази и са стране, на заврштеку првог реда исклесаног текста. Доњи део овог оквира завршава се правом линијом, која се не може у целости сагледати због оштећења на том делу. Дужина тако исклесаног поља, од шпицастог врха лука до доње линије, износи 53,5 цм, а ширина 21 цм. На бочним странама споменика уочљива је излизаност и углачаност површине, што највероватније представља траг његове накнадне секундарне употребе. На горњем делу десне бочне стране формирано је удубљење правоугаоног облика, што може представљати последицу накнадног узиђивања споменика у објекат, или је настало у контексту могуће првобитне локације споменика (сл. 6).

Ћирилички текст у овом пољу изведен је у шест редова и започиње на око 15 цм од висине зашиљеног врха лука (сл. 7). Висина исклесаних слова износи у просеку 3,5-4 цм. На целокупном споменику приметне су неравнине и бројна оштећења површине. Текст је углавном фланкиран двема дужим паралелним линијама исклесаног оквира, с тим што последње

\footnotetext{
${ }^{7}$ Оријентацију споменика посматрамо према хералдичким правилима. Види: Ацовић 2008, 80.
} 


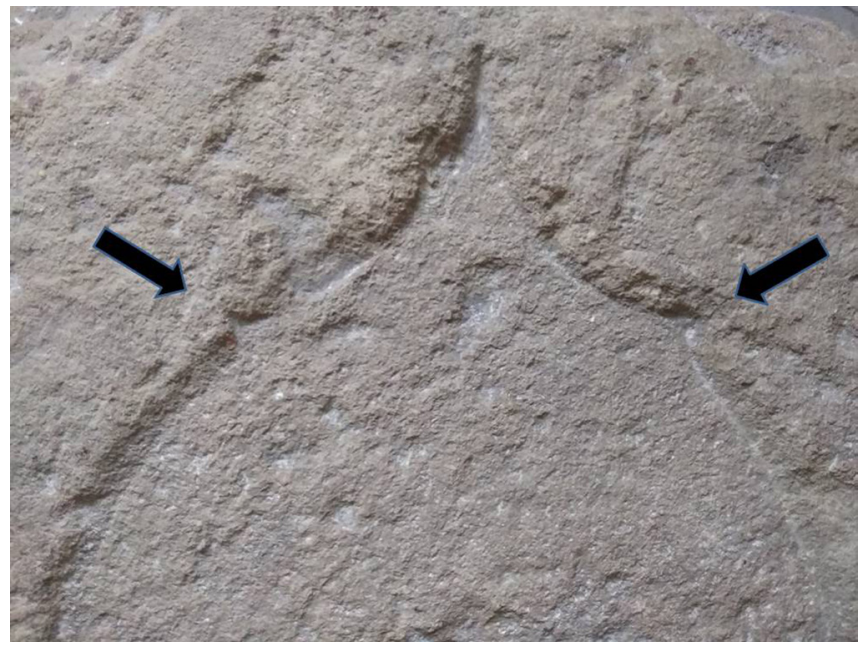

Сл. 5. Горњи део исклесане површине споменика, са карактеристичном декорацијом

Fig. 5. The upper part of the monument's carved area, with the distinctive decoration
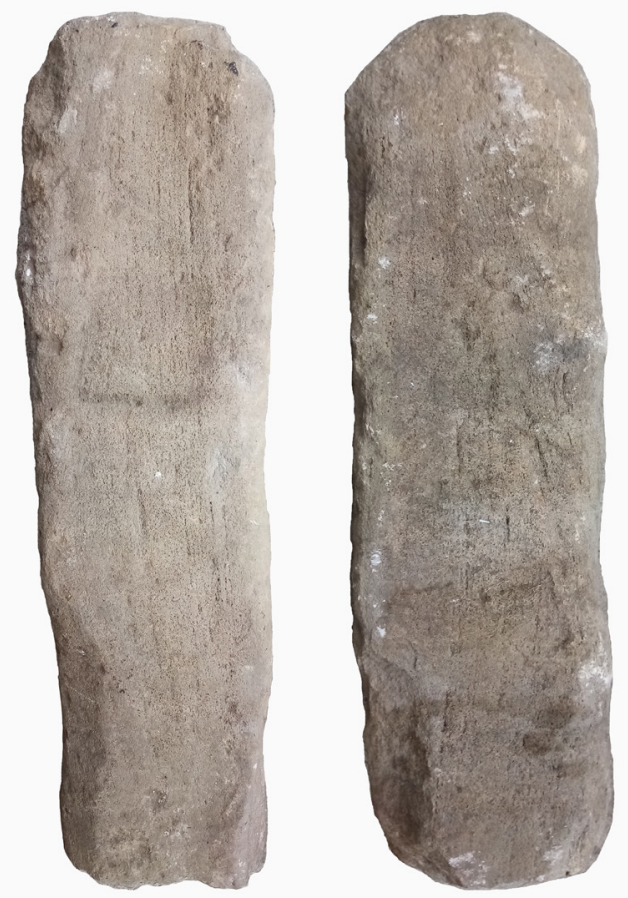

Сл. 6. Десна и лева бочна страна споменика

Fig. 6. The right and the left side of the monument 


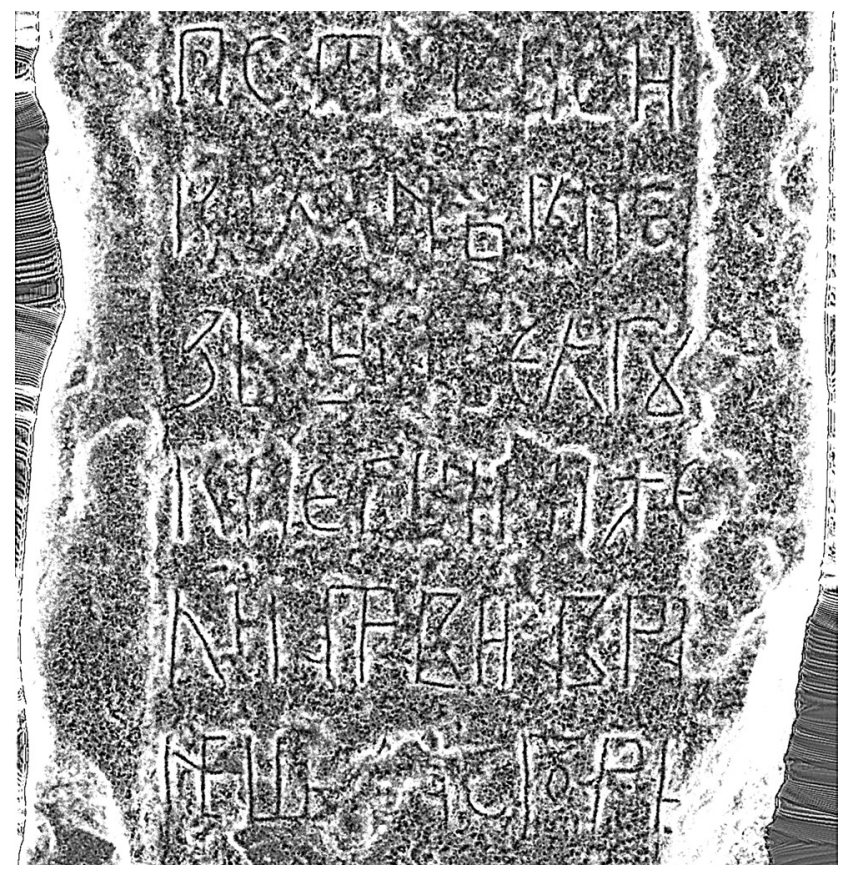

Сл. 7. Калк натписа

Fig. 7. The calque of the inscription

слово у петом реду излази ван тог простора. Највећа оштећења на тексту се запажају на срединама првог, трећег и шестог реда, као и на последњим словима у четвртом реду. Према нашем читању, текст на споменику гласи:

$$
\begin{aligned}
& \text { П[0]CT }\{\text { А }\} \text { ВьCH } \\
& \text { кАнा[ย]НьКне } \\
& \text { 乙Ь }\{\ldots\} \text { БЕЛ[Е]Г̌ } \\
& \text { КНЕГІНI }\{\text { АН }\} \text { (ђерв) } \\
& \text { ЋЇІаПР[А]ВН.АВРА } \\
& \text { неШь \{ HАÏ }\} \text { CTOP }
\end{aligned}
$$

Текст је претрпео најтеже оштећење на месту резервисаном за име кнеза који је поставио овај споменик. Може се рећи да очувани делови слова и смерови исклесаних црта на овом месту не одговарају имену „Иван”, како га је прочитао Јован Живановић 1843. године. На основу тога, претпостављамо да се и тада на овом месту налазило оштећење, те да оно није наступило као последица узиђивања у објекат, нити каснијег извлачења из њега. На овом делу је науочљивији симбол који може представљати надмет- 
нуто слово $๒{ }^{8}$ Након њега следе још два (?) симбола и чини се да оба имају доњу квачицу, па према томе могу представљати слова К, Н или ь. На основу најочуванијег симбола овог дела натписа, чини нам се смисленије да је име на овом месту могло гласити Јован (Iબ)нНь). Овај предлог би се могао оправдати и претпоставком да је у времену објављивања 1843. године натпис био у нешто бољем стању, па су тумачи овог текста могли јасније видети нека слова, нпр. последња два, што би их навело да закључе да се ради о имену Иван. Као алтернативу овом тумачењу, прилажемо претпоставку према којој

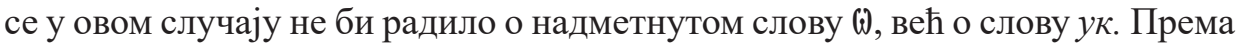
оваквом тумачењу, прва два слова имена би могла гласити $\mathrm{k} ү . . .$, а у случају да последња два слова оставимо како су некада прочитана, могли бисмо помишљати на име Вукан. Напослетку, пошто је последњи знак оштећених слова исклесан без јасно видљиве доње хоризонталне црте, у том случају можемо условно елиминисати слово $\mathbf{b}$ и узети у разматрање име које се завршава на слово К. Овакав начин писања овог слова би највише одговарао слову К са почетка другог реда, али у доста умањенијој представи (Влк?). С обзиром на висок степен оштећења овог дела текста, коначан суд о овом проблему остављамо лингвистима и стручњацима за ћириличку епиграфику. Након дела белегу кнегињи, по свему судећи следи правилно прочитано име Анђелији. ${ }^{9}$ Услед оштећења првог дела речи, не може се сасвим јасно прочитати реч која је првобитно протумачена као мајстор. Забуну додатно уноси слово Т, које по начину клесања у много већој мери подсећа на Г, каква се јављају у другим деловима текста, док је једино Т у целом тексту написано на другачији начин. ${ }^{10}$ Прво слово је готово у потпуности уништено, али би се на основу очуваног дела зашиљене горње кукице могло претпоставити да се ради о слову М. Услед велике збијености почетних слова и очуваних трагова дијакритике, претпостављамо да се највероватније ради о извесној лигатури нїі, након које би следила јасније читљива слова стоРь.

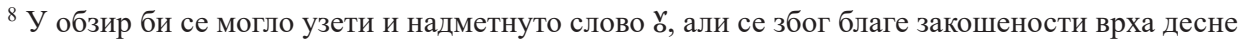

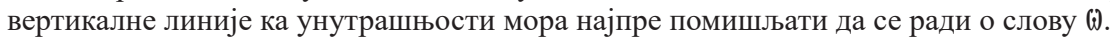

${ }^{9}$ Одбацили смо могућност да се ради о имену Јелена, иако смо узели у разматрање могућност по којој је клесар натписа услед лоше процене која је довела до недостатка простора могао слово Ћ да напише са краком на супротној страни, како би редуковао простор за наредно слово Е, које је, и као такво, изашло из предвиђеног исклесаног оквира. Уваживши мишљење проф. др Ирене Шпадијер, сложили смо се да се ипак ради о слову „ђерв”. Као други разлог за одбацивање хипотезе о имену Јелена ишао би и начин писања потенцијалног слова Н, где се на основу других појављивања истог слова уочава да клесар косу линију не исписује до самог дна, већ се она по правилу налази у горњем делу слова. Исто тако, уочљива је и дијакритика изнад слова I, што додатно потврђује да се овде не ради о том женском имену.

${ }^{10}$ Могућност да се ради о речи ктитор одбацили смо услед појављивања облог слова, по свему судећи слова $\mathrm{f}$, на средини речи, иако би таква могућност променила читав контекст и смисао натписа.
} 


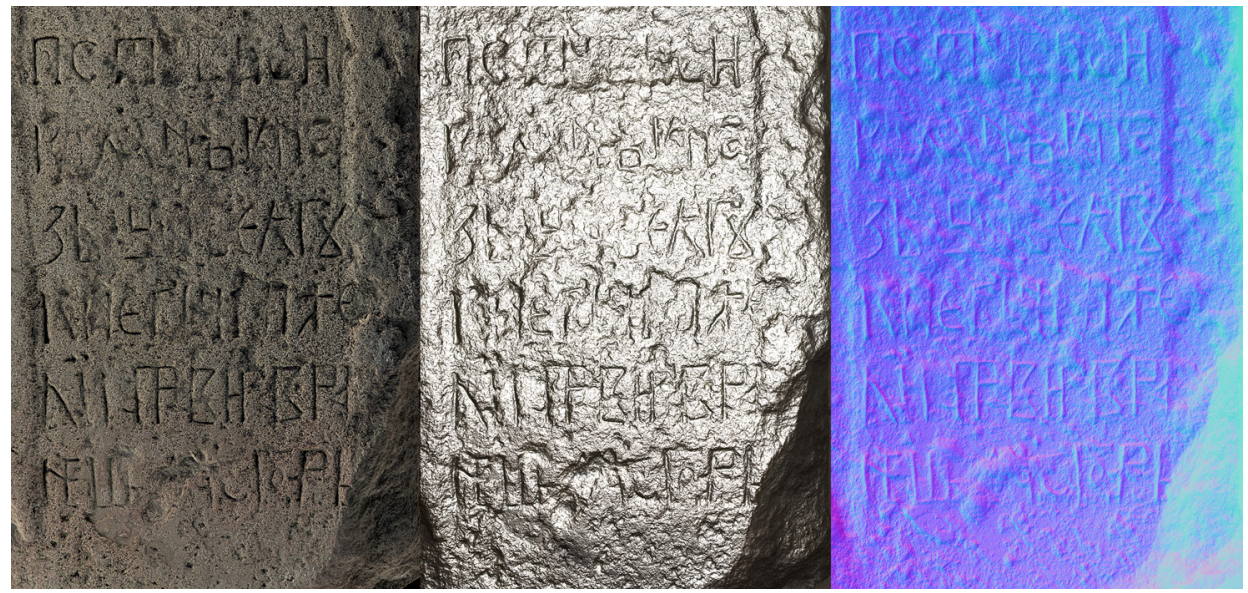

Сл. 8. Стандардни, Specular Enhancement и Normals Visualization RTI режим приказа натписа на споменику

Fig. 8. Default, Specular Enhancement and Normals Visualization RTI rendering mode of the monument's inscription

Према нашем схватању, овај натпис би у транскрипцији гласио: Постави овај камен кнез (...) у спомен кнегињи Анђелији, а прави га Вранеш мајстор. Већ на основу начина писања појединих слова, као што су $\mathrm{H}$ и $\mathrm{H}$, може се уочити одређена старија традиција исписивања натписа. У прилог томе иде и појава танког ,jер" (b), што унеколико указује на рашку традицију (редакцију). У тексту је запажена и појава „стилске симетрије”, архаичне фигуре према којој се о једној ствари говори два пута, а која води порекло још из псалама. Условно, у нашем тексту би се то могло односити на речи „камен” и „белег”. Сви ови параметри указују на одређену архаичност самог натписа. ${ }^{11}$

Како би се утврдило постојање евентуалних старијих натписа, на фронтално лице споменика је примењена RTI (Reflectance Transformation Imaging) фотографска метода, чији су резултати показали одсуство било каквих трагова раније клесарске активности (сл. 8). Овом приликом је израђен и 3D модел лица споменика на коме се налази епиграфски натпис (сл. 9). ${ }^{12}$

Индикативан елемент за стилско опредељење споменика би у овом случају био изглед уклесаног, на горњем делу лучно савијеног, а затим зашиљеног оквира, у коме је исклесан текст. Бројнији слични при-

\footnotetext{
11 Захваљујемо проф. др Ирени Шпадијер са Филолошког факултета Универзитета у Београду на корисним саветима из области средњовековне лингвистике.

12 RTI узорак и 3D модел лица споменика из Жупањевца израдио је Југослав Пендић из BioSense института у Новом Саду, на чему му овом приликом најсрдачније захваљујемо.
} 


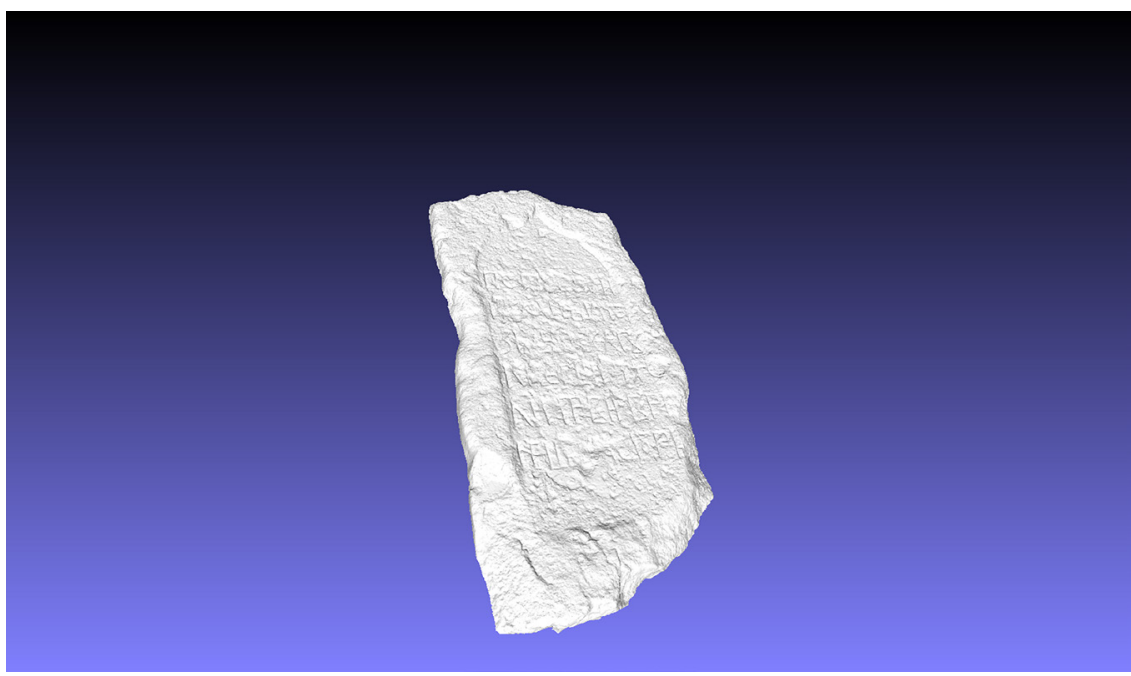

Сл. 9. 3D модел лица споменика (аутор J. Пендић)

Fig. 9. 3D model of the monument's surface (created by J. Pendić)

мерци на којима би се могао наћи овакав начин клесарске интервенције изостају на ширем простору. Најприближнија аналогија за овакав детаљ који фланкира текст налази се на надгробнику откривеном на простору испред северозападног бедема Горњег града Београдске тврђаве. Ради се о приклесаној надгробној плочи, која је припадала скупини споменика узиданих као сполије у лице бедемске куртине са кордон венцем полукружног профила у периоду између 1693. и 1697. године (Поповић 2005, 213-214, 217, Сл. 2/Кат. бр. 11). Она представља део вертикалног надгробног споменика - усадника са горњом лучно моделованом страном. Као и жупањевачки примерак, израђен је од кречњака. На предњој страни се налази поље са натписом, изведено у виду плитке нише, изнад које се налази шиљати „сараценски” лук. Натпис на овом споменику био је изведен у три реда и гласио је РАБ БӝН вАСНћ (сл. 10). Ширина споменика са Београдске тврђаве је нешто мања, док је дебљина готово истоветна са нашим примерком и износи 17 цм (Поповић 2005, 217). ${ }^{13}$ Претпостављено је да су ови вертикални надгробници-усадници могли били високи 1-1,20 м (Поповић 2005, 220), што се у великој мери поклапа са податком Тодора Бушетића о висини споменика из Жупањевца од 1,5 м (Бушетић 1903, 496). За разлику од нашег примерка, на теменом делу споменика са Београдске тврђаве налази се рељефна представа крста (Поповић 2005, 217).

13 У периоду изласка рада о овој скупини споменика, аутору Марку Поповићу нису биле познате сличне стилске паралеле за споменик под каталошким бројем 11. Види: Поповић $2005,220$. 

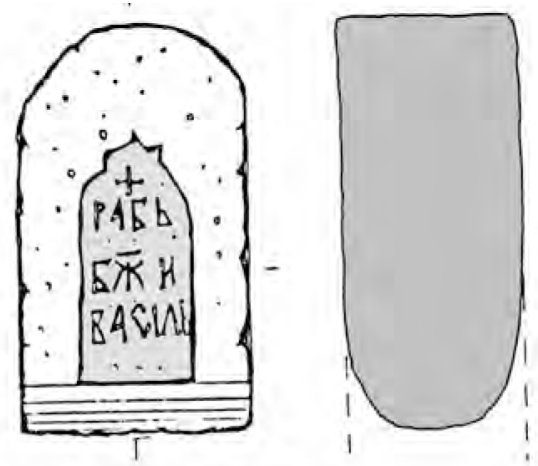

Сл. 10. Камени споменик - сполија са каталошким бр. 11, из севеорозападног бедема Београдске тврђаве

Fig. 10. Stone monument - spolia, cat. no. 11, from the north-western part of the Belgrade Fortress wall

Оштећење горњег дела споменика из Жупањевца не даје одговор на питање да ли се ради о правоугаоном или полукружном заврштеку, али је сасвим могуће да би овај споменик могао припадати првој групи споменика са Београдске тврђаве, коју сачињавају вертикални усадници правоугаоног пресека са лучно завршеним горњим делом. Такав облик споменика карактеристичан је за рано турско раздобље (Ердељан 1996, 103; Поповић 2005, 220). Ова скупина споменика из Београда, заједно са плочом „раба божјег Васила” на којој се налази сараценски лук, оквирно је датована у 17. век, првенствено према доминантним стилским каркатеристикама (рељефни двоструки крст), као и на основу контекста налаза (Ердељан 1996, 103; Поповић 2005, 221; Поповић 2006, 200). Марко Поповић истиче да се по начину клесања и облицима слова ова плоча приближава споменицима 15. века. Међутим, све њене друге карактеристке је смештају у нешто млађе раздобље, што може указивати на континуитет старијих традиција међу српским грађанством Београда у ранијем периоду турске владавине (Поповић 2005, 221).

Клесари споменика из Жупањевца и Београда су узоре за стилизацију изведену у виду „сараценског лука” могли пронаћи и на архитектури цркава моравске градитељске школе. У питању је одређени тип бифора које су на овим споменицима израђиване управо у оваквом облику. Примера ради, њих налазимо нешто раније на црквама манастира Раванице (Вуловић 1966, 173; T. XLII) или Љубостиње (Ђурић 1985, 53; Сл. 34, 36-38), док се најдиректније аналогије налазе на профаној архитектури космајских манастира са почетка 15. века, Кастаљана и Павловца (сл. 11). У оба случаја ради се о готово идентичним облицима бифора са уклесаним оквиром, на којима се чак налазе и мали 


\section{Павловац}

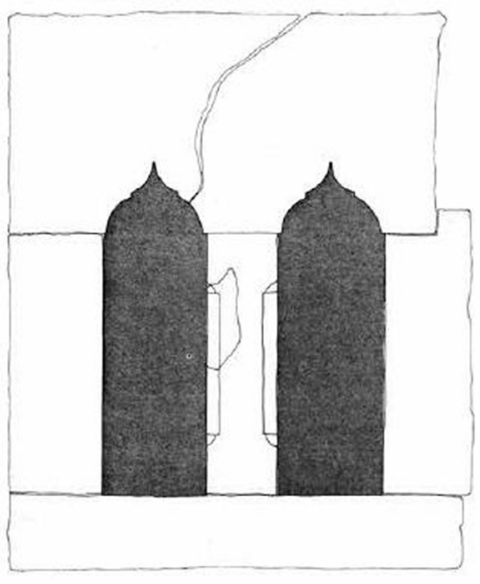

\section{Кастаљан}

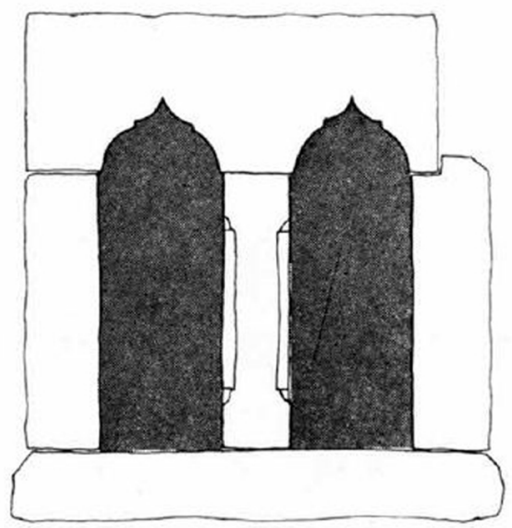

is i, 20,300

Сл. 11. Бифоре из манастира Павловца и Кастаљана

Fig. 11. Biforas from the monasteries of Pavlovac and Kastaljan

„шиљци”, попут оних исклесаних на полукружном делу мотива споменика из Жупањевца и Београдске тврђаве (Мојсиловић 1981, 132; Сл. 7; Поповић 2017, 38; Сл. 19). Овакве подударности индицирају да су можда управо овакви архитектонски делови послужили клесарима као узор. ${ }^{14}$ Такозвани сараценски или шиљсти лук, као мотив из исламске уметности, продире значајније током 16. и 17. века у српску сакралну уметност (Шево 2016, 576-577), што се може уочити на појединим споменицима тог доба, попут Цркве Св. Богородице у Ковачеву код Новог Пазара (Тодоровић 1989, 215, Сл. 2, 5) или Цркве Св. Димитрија у Митровој Реци (Премовић Алексић 2011, 472, Сл. 1, 2). Исти такав лук са „шиљцима”, који одговара онима са споменика из Жупањевца и Београдске тврђаве, али и бифорама поменутих космајских средњовековних манастира, налази се на северозападној фасади Чесме Мехмед-паше Соколовића на Београдској тврђави, подигнутој у другој половини 16. века (сл. 12) (Поповић 1980, 71-72, 76, Сл. 7).

На први поглед, поменута лингвистичка архаичност и верно опонашање одређених елемената моравске архитектуре могли би навести да се настанак овог споменика условно смести у прву половину 15 . века и доба српске деспотовине. Међутим, текст споменика упућује нас на унеколико другачије размишљање. Сама титула кнеза у периоду деспотовине била је

\footnotetext{
${ }^{14}$ Слично обликовање лука може се уочити и на делу фонтане са готичком рељефном декорацијом откривеном у комплексу средњовековне митрополије у Београду. Види: Поповић и Бикић 2004, 61; Сл. 26, 45).
} 


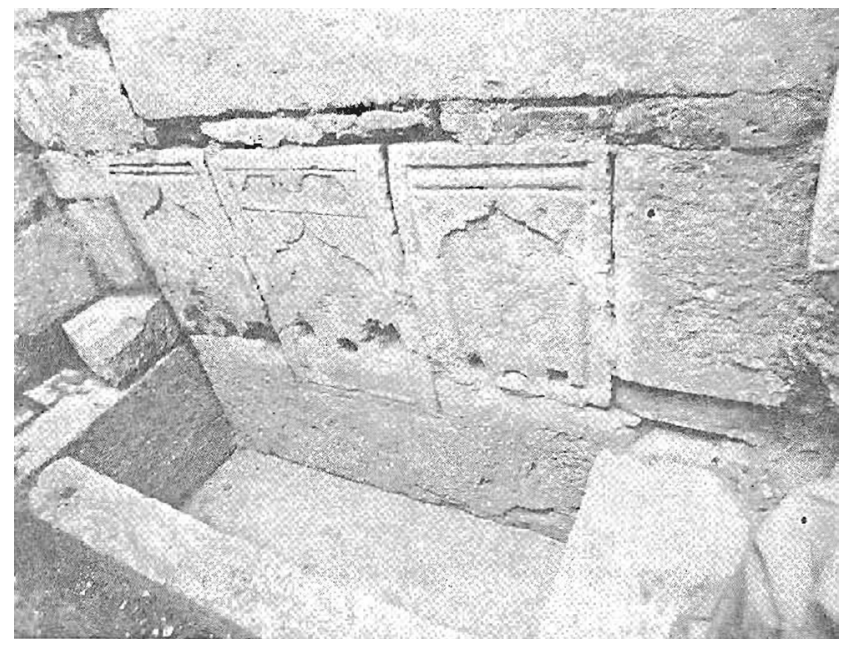

Сл. 12. Северозападна фасада Чесме Мехмед-паше Соколовића - детаљ каменог корита са декоративним плочама и отворима за луле

Fig. 12. The north-western façade of the Mehmed Paša Sokolović's Fountain - detail of the stone trough with decorative slabs and openings for the spouts

резервисана једино за службеника у рударским градовима, попут Новог Брда или Сребренице, а ту дужност углавном су обављали Дубровчани (Радојичић 1962, 52; Веселиновић 2006, 257; Ивановић 2013, 230; 277). Функција народних старешина кнезова уводи се након пада српске деспотовине 1459. године и формирања Смедеревског санџака. Ову титулу нису донела турска освајања, већ су је Османлије установиле на основу друштвеног уређења из српске средњовековне државе, чији се почеци могу пратити од титуле кнеза катуна, коју помињу домаћи и дубровачки извори. Кнезови су се у првим деценијама османске власти налазили на челу влашких заједница, да би након укидања влашког статуса у Смедеревском, Крушевачком, Видинском, Зворничком и Босанском санџаку око 1530. године постали старешине народа (раје). Они се поименце помињу већ у првим детаљним пописима након пада српске средњовековне државе у којима су регулисана њихова права и дужности (Миљковић-Бојанић 1998, 88). Њихове обавезе, као и примићура, биле су да помажу приликом прикупљања пореза, штите и чувају поверену им територију, брину о кретању становиништва и спречавају његово исељавање, као и да учествују у војним походима. Заузврат су уживали тимаре, тј. кнежинске баштине, које су биле ослобођене дажбина, као и десетак од новчаних глоба које је убирао санџак-бег (Миљковић-Бојанић 1998,90$).{ }^{15}$

\footnotetext{
15 За детаљније информације о значењу и улози кнеза у првим вековима турске управе види: Ђурђев 1948, 3-37; Миљковић-Бојанић 1998 87-97.
} 
У првим релевантним и доступним пописима кнезова Смедеревског санџака не налазимо име Иван, као што је првобитно прочитано (Миљковић-Бојанић 1998, 94). Друго предложено име нам се чини извеснијим. Име Јован чешће се појављује почевши од пописа влаха Смедеревског санџака из 1476. године, али не постоје елементи на основу којих би се географски приближили са нашим претпостављеним кнезом. ${ }^{16}$ Име кнеза Јована у Левчу срећемо и 1757. године, али се на основу стилских и лингвистичких карактеристика споменика он свакако мора одбацити као прилично позни (Павловић 2017, 348, 360). Поуздано се у Левчу 1476/7. године помињу три кнеза - Драгиша, Вукач и Ђурђ - док је у попису из 1528. убројано њих 11. У овом каснијем попису село Жупањевац се јавља у оквиру групе насеља, која су уско територијализована око самог Жупањевца (Надрље, Каленић село и манастир, Сибница, Комаране и Маслешево). На челу ове групе села налазио се кнез Пава, син Владислава, са браћом Вуком, Рајаном и Чавом и њиховим синовима. Они су уписани на почетку пописа села Маслешева (Малешева), а осталим селима су управљали преко примићура. ${ }^{17}$

Име Анђелија често се помиње у овом периоду. У српским поменицима 16-17. века уписано је 185 пута, и то у Пећком 83 пута, Крушевском 73 пута, Крушедолском 20 пута и у Врдничком 9 пута (Новаковић 1875, 41). Име кнегиње која се помиње заједно са кнезом није усамљена појава у овом периоду, али је свакако ретка. Тако се нпр. у Цркви Св. Николе манастира Лапушња, на обронцима планине Ртањ, налази ктиторски натпис на основу ког се сазнаје да је црква живописана трудом и средствима кнеза Богоја и његове госпође Маре и деие 1510. године (Кнежевић 1986, 90).

Име Вранеш на крају текста нам указује да се највероватније ради о особи влашког порекла (Храбак 1990, 21, 32). ${ }^{18}$ Након 1459. године долази до великог пустошења насеља у северној Србији, услед чега је уследила турска ак-

\footnotetext{
16 Под врховним кнезом влаха Малугом, Николиним сином, налазило се двадесет потчињених кнезова, од којих је један био Јован, Станисавов син, који је имао 19 премићура, 27 села, 290 кућа и 181 табију. У истом списку је уписан и Јованко, Станимиров син, са 8 премићура, 13 села, 256 кућа и 200 табија (види Миљковић-Бојанић 1998, 93-94). Ипак, овај кнез Јован је управљао 1476. године кнежином Моравом, са селима у околини Брвеника и Рудника, што географски не одговара локацији нашег споменика. Види: Храбак 1990, 19. Међу хришћанима-спахијама у попису из 1476. године јавља се већи број особа са овим именом, али није наведено да ли је још неко од њих могао понети титулу кнеза. Ту су уписани Јован Рудеваи, Јован син Радосаља, Јован Ресић, Јован Саничић, Јован син Радована, Јован син пребега и Јован син Војина. Види: Миљковић-Бојанић 2007, 91-93.

17 Захваљујемо др Александру Јаковљевићу из Историјског института на подацима о пописима из необјављене изворне грађе.

18 У нахији Љубовиђа је постојала утицајна влашка скупина Вранеша, чији је оснивач био кнез Херак Вранеш. Види: Тошић 1996, 101-113.
} 
ција насељавања Влаха у овим областима. Они су већ у другој деценији турске власти заузели велики део Смедеревског санџака, па је 1476. године регистровано 7.600 влашких домова, што указује на готово трећину читаве популације. У поречју Западне Мораве тај број је износио и више од једне трећине (Храбак 1990, 13-14). Из текста се да закључити да је овде реч о занатлији, мајстору клесару, чији нам други радови нису познати. Најближа географска аналогија за овакав начин „потписивања” сопственог дела налази се у оближњем манастиру Љубостиња. Градитељ Боровик Рад (Боровић Раде, у народној песми Раде неимар) доста раније је од времена жупањевачког клесара оставио свој потпис на прагу између припрате и наоса Цркве Успења Пресвете Богородице у Љубостињи, са звањем ПРОТонанНТОРЬ (Ђурић 1985, 45; Сл. 11).

Услед потешкоћа због непостојања довољног броја релевантних паралела за овакав тип надгробног споменика, принуђени смо да се за његово ближе датовање руководимо хронолошким опредељењем јединог нам познатог аналогног примерка. Иако је читава скупина надгробних споменика из Београда оквирно датована у 17. век, склони смо да период настанка нашег примерка нешто шире датујемо, у период 16-17. века, с тим што извесну предност дајемо 16. веку као раздобљу могућег настанка. То је првенствено условљено чињеницом да овај споменик карактеришу већ поменути архаични елементи, чије се постојање може наћи још у времену прве половине 15. века, што је у палеографском аспекту примећено и за паралелу из Београда (Поповић 2005, 221). Стога се 16 . веку, као времену када су те традиције још увек могле бити неговане, даје извесна предност. Притом, од 16. века долази и до веће популаризације оријенталних стилских елемената, попут „сараценског лука", који је све чешће заступљен у српској сакралној уметности (Тодоровић 1989,215 , Сл. 2, 5; Шево 2016, 576-577), док се идентичан облик лука оном из Жупањевца јавља и на појединим исламским споменицима 16. века (Поповић 1980, 71-72, 76, Сл. 7). На крају, у овом столећу налазимо и сличне примере потписивања супруга локалних кнезова, попут оног на ктиторском натпису манастира Лапушње из 1510. године (Кнежевић 1986, 90).

Приметно је постојање одређене сличности у начину клесања појединих слова између споменика из Жупањевца и Београдске тврђаве, што одаје утисак да су споменици рађени у сличном периоду и на сличном географском простору. Начин обликовања слова и избор специфичног и ретког орнамента клесара могу указивати да аутори потичу из исте или сличне клесарске школе, док би помисао да се ради о истој особи засад била једино у домену претпоставки. Ипак, одређене закључке о лингвистичким и епиграфским својствима текста мора донети стручњак из тих области. 
Ако се има у виду тако конципиран текст споменика, није сасвим известан његов фунерарни карактер. На њему нема уобичајеног дела раба Божјег, нема године упокојења, а поменуто је и више личности, што не представља уобичајени текст епитафа. Мора се претпоставити и то да је овај камен, за нас још увек анонимни кнез, поставио у спомен („белегу”) кнегињи Анђелији као сведочанство о неком значајнијем догађају који се могао догодити на том месту. Пошто се камен, условно, налазио крај пута који спаја два стара насеља, Жупањевац ${ }^{19}$ и Богалинац ${ }^{20}$, он је ту могао бити постављен у улози својеврсног подсетника или кенотафа, који је на таквом месту био приступачан пролазницима и путницима. Сличних споменика на овом месту није било, као ни трагова који би указивали да се на том месту налазила некропола. По свом карактеру, овај споменик нас у великој мери подсећа на споменик деспоту Стефану Лазаревићу, који се налази у порти данашње цркве села Марковац и сведочи о месту његове смрти (Мишић 2008, 1-6). Претпостављени меморијални карактер споменика имплицира делимичну исправност народне традиције. Она овај споменик није повезала са гробним местом неке важне личности, већ са одређеним догађајем. ${ }^{21} \mathrm{Ha}$ основу самог споменика, као и према видљивој речи Бетег на њему, читав део данашњег села је понео назив Белега, док су помен кнегиње на њему становници с временом повезали са кнегињом Милицом, која је и боравила недалеко одатле крајем 14. века. Услед одсуства прецизних података о тачној првобитној локацији споменика, као и чињеници да се ради о некарактеристичном епитафском натпису, питање првобитне намене споменика мора остати отворено.

Било да се ради о неком локалном кнезу о коме није остало података у писаним изворима, или кнезу који је владао у периодима између настанка дефтера па стога није у њима уписан, као и у случају да је у питању један од важнијих народних вођа чије име нисмо успели правилно да протумачимо а који се налази у пописима, ради се о једином епиграфском споменику са територије данашњег Левча из периода позног средњег века и периода раније османске власти. Први његов значај огледа се у томе што рефлектује

\footnotetext{
19 Жупањевац се као манастир помиње 1398. године, а као насеље први пут 1530. године. Највероватније је убележено и у непубликованом дефтеру из 1476. године. види: Младеновић 2007, 234; MAD 506 Numaralı Semendire Livâsı İcmâl Tahrîr Defteri (937/1530) 2009, 39.

${ }^{20}$ Село Богалинац је, за сада, први пут убележено 1502. године. Види: Катић и Амедоски 2017, 13.

${ }^{21}$ Ради се о већ поменутом доласку кнегиње Милице/Силне Јерине и њеним сукобом са властелином Николом, који је гађан топовима са те локације. Види: Живановић 1843, 194; Марковић 2004, 163.
} 
клесарове афинитете ка специфичним елементима, који се подједнако могу наћи на делима моравске архитектуре и исламске уметности, што представља специфичност и редак случај на овим просторима, а и шире. Друго, натпис сведочи о друштвеним категоријама и присуству досељених припадника влашке племенске групе током 16-17. века, као и о самом значају села и манастира Жупањевац тог доба. ${ }^{22}$ На крају, ради се о специфичној врсти споменика који сведочи и о материјалној снази локалног жупањевачког кнеза да физички обележи одређену локацију, њему тада важну, у спомен на своју кнегињу.

\section{БИБЛИОГРАФИЈА}

Ацовић, Д. 2008. Хералдика и Срби. Београд: Завод за уџбенике.

Actes de l'Athos. V. Actes de Chilandar. 1915. у Византійскій временникъ. Приложеніе къ ХІХ тому. № 1, ур. R. P. Louis Petit и В. Korablev, 369-651. Петроградъ : Типографія Императорской Академіи Наукъ.

Bešlagić, Š. 1982. Stećci - kultura i umjetnost. Sarajevo: IRO Veselin Masleša.

Благојевић, М. 1999. Белег. у Лексикон српског средњег века, пр. С. Ћирковић, Р. Михаљчић, 38-39. Београд: Knowledge.

Бушетић М, Т. 1903. Левач. у Насеља српских земаља, књига II. Српски етнографски зборник, књига пет, ур. Ј. Цвијић, 459-511. Београд: Српска краљевска академија.

Веселиновић, А. 2006. Држава српских деспота. Београд: Завод за уџбенике и наставна средства.

Вуловић, Б. 1966. Раваница, њено место и њена улога у сакралној архитектури Поморавља. Саопштења VII. Београд: Републички завод за заштиту споменика културе. Грковић, М. 2013. Резултати археолошких ископавања цркве у средњовековном граду Жупањевцу. Гласник ДКС 37: 89-92.

Ђурђев, Б. 1948. О кнезовима под турском управом. Историјски часопис I: 3-37.

Ђурић, С. 1985. Љубостиња. Црква Успења Богородичиног. Београд: Просвета, Републички завод за заштиту споменика културе.

Ердељан, J. 1996. Средњовековни надгробни споменици у области Раса. Београд: Археолошки институт, Музеј Рас, Нови Пазар.

Живановић, J. 1843. Придатци къ србскимъ споменицима. Градъ Жупанъвацъ (Саобштіо Іованъ Живановићъ, учитель Свилаеначкій.). Подунавка. Додатакъ къ србскимъ новинама за годину 1843: 193-194.

Зечевић, Е. 2005. Мраморје - стећйи у западној Србији. Београд: Српско археолошко друштво.

\footnotetext{
22 За археолошке податке о манастиру Жупањевац у времену османске владавине види: Ристић 2015, 115-128.
} 
Ивановић, М. 2013. Властела државе српских деспота. Докторска дисертација, Универзитет у Београду.

Каниц, Ф. 2007. Србија, земља и становништво, од римског доба до краја ХІХ века. Прва књига. Београд: Логос Арт.

Катић, Т. и Амедоски, Д. 2017. Караванџије нахије Петруш из Левча 1502. године. Мешовита грађа ХХХVIII: 7-25.

Кнежевић, Б. 1986. Манастир Лапушња. Саопштења XVIII: 83-114.

Лома, А. (ур.) 2008. Етимолошки речник српског језика, свеска 3: БЕ-БЈ. Београд: САНУ Одељење језика и књижевности, одбор за етимолошки решник, Институт за српски језик САНУ, етимолошки одсек.

MAD 506 Numaralı Semendire Livâsı İcmâl Tahrîr Defteri (937/1530). 2009. yp. Y. Sarınay, M. Budak, Ö. Bayır, A. Zeki Izgöer и M. Yüzbasioğlu. Ankara: T. C. Başbakanlık Devlet Arşivleri Genel Müdürlüğü.

Марковић, С. 2004. Приповетке и предања из Левча - нови записи. КрагујевацБеоград: Чигоја штампа.

Миљковић-Бојанић, Е. 1998. Кнежинска самоуправа у Смедеревском санџаку у другој половини XV и првој половини XVI века. Зборник Матице српске за истоpujy 57: 87-97.

Миљковић-Бојанић, Е. 2007. Хришћани спахије у Смедеревском санџаку у другој половини 15. века. у Моравска Србија, историја-култура-уметност. Зборник радова са међународног научног скупа одржаног 29. септембра у Крушевиу и 30. септембра 2007. године у манастиру Наупаре, ур. С. Мишић, 85-94. Крушевац: Историјски архив Крушевац, Одељење за историју Филозофског факултета у Београду.

Мишић, Б. 2008. Споменик на месту смрти деспота Стефана Лазаревића. Београд: Завод за заштиту споменика културе града Београда.

Младеновић, А. 2007. Повеље и писма деспота Стефана. Београд: Чигоја штампа. Мојсиловић, С. 1981. Средњовековни манастир у Павловцима на Космају. Caonитењь ХIII :127-46.

Новаковић, С. 1875. Српски поменици XV-XVIII века. Гласник Српског ученог друштва 42: 1-152.

Павловић, М. 2017. Смедеревски саниак 1739-1788. Нови Сад: Матица српска.

Поповић, М. 1980. Чесма Мехмед паше Соколовића. Годишњак града Београда XXVII: 71-81.

Поповић, М. 2005. Трагови једне београдске некрополе 17. века. Наслеђе VI: 213-226. Поповић, М. 2006. Београдска тврђава. Београд: Јавно предузеће „Београдска тврђава".

Поповић, М. 2017. Сакрално окружење Београда у доба деспота Стефана. у: 600 година манастира Павловац, ур. В. Катић и Н. Марковић, 11-44. Младеновац: Градска општина Младеновац.

Поповић, М. и Бикић, В. 2004. Комплекс средњовековне митрополије у Београду. Београд: Археолошки институт. 
Премовић Алексић, Д. Р. 2011. Прилог проучавању скулптуралних портрета ктитора цркава у околини Новог Пазара. Зборник радова Народног музеја XX-1: 471-487. Радојичић, Н. 1962. Закон о рудницима деспота Стефана Лазаревића. Београд: Научно дело, САНУ.

Ристић, А. 2015. Средюовековна жупа Левач у светлу археолошких истраживања, мастер рад, Универзитет у Београду.

Стојановић, Љ. 1902. Стари српски записи и натписи, књига І. Београд: Српска краљевска академија.

Стојановић, Љ. 1923. Стари српски записи и натписи, књига четврта. Сремски Карловци: Српска краљевска академија.

Тодоровић, Д. 1989. Црква Св. Богородице у Ковачеву. Саопштењ 223.

Тошић, Ђ. 1996. О влашкој скупини Вранеши у нахији Љубовиђа. Милешевски записи 2: 101-113.

Храбак, Б. 1990. Власи старинци и досељеници у поречју Западне Мораве (до 1570. године). Зборник Народног музеја Чачак XX: 5-45.

Шафарикь, Др. Я. прир. 1862. Хрісовоула цара Стефана Душана, коіомъ оснива монастиръ Св. Архангела Михаила и Гаврйла у Призрену године 1348?. Гласникъ Друштва српске словесности XV: 266-317.

Шево, Љ. 2016. Исламски утицај на српску уметност у доба отоманске власти, у Византијско наслеђе и српска уметност II. Сакрална уметност српских земаља у средюем веку, ур. Д. Војводић и Д. Поповић, 575-579. Београд: Српски комитет за византологију, ЈП Службени гласник, Византолошки институт САНУ. 


\section{Aleksandar Ristić \\ National Library "Dr Milovan Spasić" Rekovac \\ Faculty of Philosophy, University of Belgrade \\ AN EPIGRAPHIC MONUMENT FROM THE VILLAGE OF ŽUPANJEVAC IN THE COLLECTION OF THE NATIONAL MUSEUM IN KRAGUJEVAC}

Keywords: stone monument, Cyrillic inscription, National Museum in Kragujevac, Županjevac, Levač, Belega, prince, Ottoman period

In the Archaeological Collection of the National Museum in Kragujevac, one stone monument originating from the village of Županjevac (Municipality of Rekovac) can be found. The inscription on this monument was read by the teacher Jovan Živanović in 1843 and thereafter published in the paper "Podunavka". There, we can find the following version of the reading of the inscription: "This stone was set by prince Ivan-beg in memory of princess Andelija, and it was made by Vraneš the Craftsman". Later, authors such as Felix Kanitz and Todor Bušetić briefly mentioned this stone monument in their works. In this paper, we attempted to provide a more detailed physical description and stylistic analysis of the monument.

Our reading of the text is quite similar to the original one, although we cannot accept the reading of the prince's name as Ivan. Based on few carvings from the heavily damaged part of the inscription, our opinion is that his name could possibly be read as Jovan or Vukan. By applying the RTI photographic method, we concluded that there are no traces of a potential older inscriptions on this monument.

The text is positioned in the engraved central part of the stone. That part has a specific "Saracen" arc, which can be found on some medieval biforas, such as those from the monasteries of Pavlovac and Kastaljan from the first half of the $15^{\text {th }}$ century, as well as on some parts of early Islamic monuments from the $16^{\text {th }}$ century. Our closest and only parallel is to be found on a single $17^{\text {th }}$ century gravestone from the Belgrade Fortress. Based on the palaeographic and already mentioned stylistic details, our opinion is that the monument originates from the $16-17^{\text {th }}$ century, but more likely the $16^{\text {th }}$ century. It is important to notice that this kind of text doesn't leave an impression that the stone had a funerary character; it is more likely to have been a reminder of some event that happened at that place. This stone is the only known epigraphic monument from the area of present-day Levač that originates from the Late Medieval and Early Ottoman period. 